\begin{tabular}{lll}
\hline Vol. XIV. & APRIL, I905
\end{tabular}

\title{
FEDERAL CONTROL OF CORPORATIONS.
}

"Inasmuch as practically all the important corporations of the present time are engaged in interstate commerce, and as the United States has the right to fix conditions to this license to engage in interstate commerce, this system would enable the Federal Government to reform the present condition of corporate business in all its important features."

In these words Mr. Garfield, Commissioner of Corporations, states the object of his proposal that every corporation shall be required to obtain a Federal license before engaging in interstate commerce. It is not to regulate interstate commerce, but to regulate "all the important corporations" doing business in the United States.

This object not being within the lawful field of Federal action, legislation to this end would be unjustifiable; but yet the courts could hardly declare it void. Although unconstitutional, it would probably stand as valid, beyond the reach of constiutional law, because the motives of Congress are not to be made the subject of judicial inquiry, but are presumed to be in accord with the constitution. No Congressman may, under his oath, vote for any bill, unless in his judgment it is called for to effect some purpose within the domain of Federal action; yet a bill not intended for any such purpose, but appearing to relate to a subject within that domain, may become a law safe from judicial attack. This fact is too little recognized. It is generally thought that a law is necessarily justified by the constitution, unless it is of such a character that the Supreme Court should declare it void. It is not commonly appreciated that while constitutional law, administered by the courts, is our great safeguard against unconstitutional action by Congress, it is not allsufficient. 
To say that the purpose of this proposal is not to regulate interstate commerce but to regulate "all the important corporations," is not to criticise Mr. Garfield personally. He has not in this struck out upon a new path. During the two years or so of consideration which preceded the passage of the Anti-Trust Act of 1890, the evident purpose of those who advocated some such legislation-and hardly any one in Congress ventured to oppose-was to destroy or curb combinations of capital without discrimination as to whether they operated in one state only or in more than one. The relation to interstate or foreign commerce was thought of only as giving a basis of jurisdiction. Except for the limitations upon the power of Congress, the trade or commerce referred to in that act would have been unlimited. The limitation was made, not because the purpose was limited, but in order to keep within the jurisdiction of Congress. Mr. Knox, in his Pittsburg address in October, I902, came near to the suggestion of Mr. Garfield when he said: "It seems reasonable to say that it (Congress) can, in the exercise of this power (to regulate interstate commerce) deny to a combination whose life it cannot reach the privilege of engaging in interstate commerce except upon such terms as Congress might prescribe to protect that commerce from restraint." The messages and speeches of President Roosevelt show, in regard to anti-trust legislation, that in his mind the aim is to reach the large corporations and to regulate them, not specially in matters affecting interstate and foreign commerce, but generally as to their outside dealings and their internal affairs, for the protection not only of the public, but also of those who are or may become their creditors or stockholders.

That it is not the real purpose of Mr. Garfield's scheme to regulate interstate commerce, is made reasonably clear by the fact that it affects only corporations as distinguished from unincorporated companies, partnerships and individuals. If a partnership in the grocery business in Portchester sells or buys across the state line in Connecticut, no license is required. But if the partnership is changed into a corporation, with the same persons interested and employed and with the same capital, a license must be taken. So far as interstate commerce is concerned, there is no change involved. Business goes on substantially as before. Possibly the change is known to but few. Is there any conceivable reason why the mere incorporation of those who are doing the business shall call for Federal interference under the power to regulate interstate commerce? Suppose that an association is organized having a large capital and intending to do a large business in two or more states. It may or may not be incorporated. 
According as it is or is not, a license is or is not required. Is there any reason in this? How many persons know whether the business of John Wanamaker is done by a corporation, a firm or an individual? And what difference does it make as regards interstate commerce or any public interest? Does the difference give any reasonable basis for differentiation as to whether a license shall or shall not be required for interstate commerce? Clearly, if the purpose were to regulate interstate commerce, a license would be required from an unincorporated association, a partnership or an individual, as well as from a corporation. Will it be proposed to make the law apply to unincorporated joint stock companies? A stop cannot logically be made there. An unincorporated joint stock company is a partnership. The difference between such a company and an ordinary partnership does not concern the public. It involves no difference of power as to commerce. Then the law should be extended to partnerships. And why stop there? Why should a license be required to enable two men in partnership to buy and sell across a state line and not to enable one of them alone to do so? Shall the law then be extended to individuals? Then the New Hampshire farmer will be barred from crossing the Connecticut River to sell his butter, his eggs or his hay in Vermont, unless he shall have taken a license from the Federal government and put himself under the supervision of its Commissioner.

That the law is to apply to all corporations, big and little, is, perhaps, further evidence that what it is sought to affect is corporate organization and management rather than interstate commerce; although possibly the truer view is, that, the purpose being to regulate only "the important corporations", it was seen to be necessary to include all corporations, lest this purpose might be made so clear that the courts could see it, and, seeing it, might declare the law void.

But doubtless there are some who are quite content that, under the cloak of a constitutional power, Congress should legislate for a purpose outside of its jurisdiction, if they think that Federal jurisdiction ought to cover such a purpose; and who will consider only the question, Is it reasonable and desirable that the Federal jurisdiction be extended to cover the purpose of this scheme?

It is important, then, to understand how much it is proposed to bring within the domain of Federal action. From the sentence quoted above it appears to be the intention "to reform the present condition of corporate business in all its important features." The business of most stock corporations-all except the few which con- 
fine their operations to a single state-is to be reformed "in all its important features." That this phrase is not carelessly used, but means what it seems to mean, is shown by the context. In the next preceding paragraph (Report, p. 45), it is said: "Congress would grant to corporations that meet the proper conditions power to engage in interstate commerce; would fix the conditions under which their business should be done in such manner as to remedy the present defects in the state corporation law $* * *$ " And immediately before that is a statement of the principal features of the plan, substantially as follows: Prohibition of corporations from engaging in interstate commerce without a Federal franchise or license (with protection to those having such franchise or license) ; imposition of "requirements as to corporate organization and management as a condition precedent to the grant of such franchise or license"; "requirement of such reports and returns as may be desired as a condition of the retention of such franchise or license," and "the right to refuse or withdraw such franchise or license in case of violation of law, with appropriate right of judicial appeal to prevent the abuse of power by the administrative officer." The scope of the intended reform is further indicated by the preceding statements as to evils to be cured (Report, pp. 35 et seq.), especially the following: "Under present industrial conditions, secrecy and dishonesty in promotion, over-capitalization, unfair discrimination by means of transportation and other rebates, unfair and predatory competition, secrecy of corporate administration and misleading or dishonest financial statements, are generally recognized as the principal evils." It is intended that a corporation applying for a license shall undo what has been done, so far as may be necessary to make its organization, capitalization, etc., conform to principles laid down by Congress. This requirement is proposed on page 60 of the Report: "That corporations taking a Federal license should conform the status of their capital stock, bonds and indebtedness to principles laid down by the act." See also the query on page 62: "Can the necessary reorganization of corporations be accomplished under all the state laws?" By the imposition of conditions on the grant and continuance of the license to engage in interstate commerce, Congress is to reform corporate business "in all its important features"-as to organization, as to capitalization and indebtedness, as to publicity in respect to organization and promotion, as to management and the responsibility of directors, as to methods of competing for trade and other methods of business, as to making known business and financial conditions, for the benefit of the public and of the stockholders. Under this plan, 
the field of Federal regulation is nearly co-extensive with the present field of State legislation as to corporations. At the outset, perhaps, the only penalty of disregard of Congressional regulations may be loss of privilege of doing interstate business. That is a severe penalty. But if the law, in this shape, shall be accepted as constitutional, it will probably not be long before Congress will make its regulations more general and prescribe other penalties, with the final result that substantially all legislative jurisdiction (and to a large extent judicial jurisdiction as well), as to all stock corporations, except a small -number of unimportant ones, will be taken from the states and vested in the Federal Government.

Are we ready so to increase the powers of the Federal Government and diminish the powers of the states? To use the words of Mr. Garfield in speaking of the alternative plan of Federal incorporation, which seem to be equally applicable to the license plan, are we ready to make such a "tremendous change toward centralization"? To state the question is to answer it, unless we are willing to bid farewell to the fundamental theory of the Federal Constitution and to call the wisdom of the Fathers folly when applied to the conditions of to-day. And if, notwithstanding this, we must seriously entertain the proposal, may we not reasonably ask that the Commissioner of Corporations shall first report what amendments to the Constitution will be necessary to subject Congress, after such transfer of jurisdiction, to those constitutional limitations which are now operative only as against the states, such as the prohibition against laws impairing the obligations of contracts and the prohibitions of the Fourteenth Amendment?

The fact that the scheme involves "a tremendous change towards centralization," at least calls for a very careful examination of the reasons advanced in its favor. Though the constitutional objection be put aside, the evils sought to be cured must be found to be real and important and other adequate remedies must be undiscoverable, if assent is to be given to so radical a change. It must at least appear that there are definite evils springing from incorporation, curable by legislative remedies which the states cannot or will not apply, and that such remedies will do more good than harm.

Diagnosis is the first requisite. The evils must be found before remedies are considered.

There are evils peculiar to the business of transportation. As to interstate transportation, Congress has full power of regulation. In legislating under this power, Congress deals with that business; its regulations act upon corporations and natural persons as well. That 
such regulations specially affect railroad companies, is not because they are incorporated, but because they are engaged in such business. If Congress wishes to regulate express transportation, its power is no greater as to the business of the Wells Fargo Express Company, which is incorporated, than as to that of the Adams Express Company, which is not. The basis of jurisdiction is the business done and not the character of those who do it. The evils connected with transportation should be dealt with by themselves. They give no basis for Federal control of corporations generally.

Attention may therefore be confined to industrial corporations. If the proposed scheme can be justified, it must be because of evils springing from the business and dealings of such companies. And it is quite evident that Mr. Garfield had such companies especially in mind in making his proposal.

Among the evils enumerated in the report is over-capitalization. Doubtless the views of the Commissioner are in harmony with those of Mr. Knox expressed in his Pittsburg address in October, I902, reported by him to the Senate in January, I903. Mr. Knox calls over-capitalization the chief of the noxious features of trusts "and the source from which the minor ones flow ;" And he defines it as follows: "Over-capitalization does not mean large capitalization or capitalization adequate for the greatest undertakings. It is the imposition upon an undertaking of a liability without a corresponding asset to represent it." Obviously he uses the word "liability" in the broad sense which includes the so-called liability arising from the issue of stock. When, for example, property worth $\$ 5,000$ is represented by $\$ 10,000$ of stock or property worth $\$ 50,000,000$ is represented by $\$ 100,000,000$ of stock, there is over-capitalization, the evil named as the chief of "the noxious features of trusts" and the source of the minor ones.

Over-capitalization is an evil. But its seriousness is exaggerated. It is usually foolish; it is harmful in ways not generally appreciated; but it is not the sturdy criminal which it appears to the popular imagination. Reference may again be made to Mr. Knox's address. He describes the evil of over-capitalization as follows: "Therefore [that is, because it imposes upon an undertaking a liability without a corresponding asset to represent it], over-capitalization is a fraud upon those who contribute the real capital, either originally or by purchase, and the efforts to realize dividends thereon from operations is a fraudulent imposition of a burden upon the public." $\mathrm{He}$ seems to find an injury to those who become participants in corporate enterprises, and an injury to the outside public. 
Is there any substance in the suggestion of this outside injury? In effect, it is said that a company having a million of assets will make greater efforts for profits, if it has issued two million of stock to represent such assets than if it has issued only one million; or, in other words, that corporate energy is increased or decreased by raising or lowering the nominal capital representing a given amount of assets. Is this one of the things which experience teaches? Do not corporations do their best to make profits without regard to the amount of their capitalization? And is there any diminution of effort when the assets have grown very largely in excess of the capital, as in the case of the Standard Oil Company? Over-capitalization, of course, does not increase the power to make profits. The power of a corporation in the business world, so far as it depends upon capital, depends upon actual capital, upon its real assets, not upon its nominal capital. Calling a penny a dollar will not increase its purchasing power in the market.

Mr. Knox says that over-capitalization is "a fraud upon those who contribute the real capital, either originally or by purchase;" that is, where the capitalization is in stock only, those who take stock from the company or those who buy stock after issue. This evil-if it be assumed that over-capitalization by itself may work fraud-affects only those who become participants in corporate enterprises. Other evils enumerated by Mr. Garfield are secrecy and dishonesty in promotion, secrecy of corporate administration and misleading or dishonest financial statements; like evils are described by Mr. Knox as lack of publicity of operation and insufficient personal responsibility of officers and directors for corporate management. These èvilsand the evil of over-capitalization, if it be assumed to open the door to fraud upon purchasers of stock-relate chiefly; if not exclusively, to the interests of those who are or would become interested in corporations as holders of their stocks or obligations. Remedies are called for, if at all, for the protection of investors or speculators in corporate securities. Secrecy and dishonesty in promotion, secrecy in administration, and misleading financial statements work wrong in inducing purchases of corporate securities. Publicity is desired that those who buy such securities may know what they buy. Responsibility of officers and directors is essential to the protection of corporate creditors and stockholders. All these evils relate to those who may be called the insiders, those who are interested in the profits to be made and in the application of such profits, those who are the real owners of the corporate assets. Doubtless, there are such evils, just as there are evils in horse trading and in every business in 
which men engage. But do these evils call for Federal interference? If remedies beyond those open by common law or by existing statutes are needed, cannot the states supply them? And is there any reason for presuming that they will not do so? Fraud in sales is essentially the same, whether the sales are of horses or of stocks; whether of stocks of companies operating in one state or of companies engaged in interstate commerce. And sales of one kind or another are not often interstate transactions. With respect to sales made in this state, whether at private sale or on the exchange, and whatever is sold, the Legislature of this state has ample power to enact any needed remedies for fraud. As to corporate management and the responsibility of officers and directors, it is a common but mistaken notion, that New Jersey, for example, sends its corporations out to do business in other states under lax regulations, and that such other states are powerless to impose proper restraints. This is a mistaken notion, because there is no such laxity in the New Jersey law and because a state is not powerless with respect to foreign corporations. It may exclude them, or it may admit them upon such conditions as it may impose. The power and willingness of the states to provide remedies with respect to the management of foreign corporations and responsibility therefor, is indicated by the law of New York, which requires annual reports from foreign and domestic companies and which imposes upon the officers and directors of foreign and domestic companies alike liabilities for making unauthorized dividends, unauthorized indebtedness, unlawful loans to stockholders, false certificates, etc. (Sec. 6, Stock Corporation Law). There is plenty of assertion of the need of Federal interference, but it in no way appears, with relation to the evils already mentioned, that the states cannot or will not apply any needed remedies. If there is any need of Federal interference, it must be because of other evils.

The evils above-mentioned are not those which the early octopus hunters were after. They regarded the trusts as bad because of their power; because of the injury which by use of such power they would do to outsiders; because they could and would drive smaller competitors out of business, and having got rid of competition, injure consumers by raising prices. President Cleveland expressed this thought in his message of December 3, I888, when he said: "As we view the achievements of aggregated capital, we discover the evidence of trusts, combinations and monopolies, while the citizen is struggling far in the rear or is trampled to death beneath an iron heel." A year later President Harrison, raising the question of restraining the trusts, said: "When organized, as they often are, to crush out all 
healthy competition and to monopolize the production or sale of an article of commerce and general necessity, they are dangerous conspiracies against the public good, and should be made the subject of prohibitory and even penal legislation." And accordingly prohibitory and penal legislation was enacted by the passage of the AntiTrust Act of 1890 . Here was shown no concern for those who might wish to become interested in trusts, no desire to make it perfectly safe to come in and share in their profits. The trusts were treated as in themselves criminal and purchasers of trust securities were regarded as participes criminis. No change of attitude appears in the messages of President Cleveland or President McKinley. A new departure was taken by President Roosevelt in his message of December 3, Igor. Realizing that large industrial combinations were needed, especially in view of international competition, and should not be destroyed or prohibited, he points out over-capitalization as one of the chief evils connected with them, not then going so far as Mr. Knox went a year later, when he called this the chief evil and the source of the minor evils of trusts, but naming no other specific evil; he insists that corporations, permitted to invite capital from the public should do so upon truthful representations as to the value of the property in which the capital is to be invested; and suggests publicity as "the only sure remedy which we can invoke."

It is submitted that the evils of over-capitalization, fraud in promotion, deceit in financial statements, dishonesty in corporate management, or any other evils touching those who are or would become participants in industrial combinations, are completely remediable by state legislation and afford no reason for Federal control. If Federal control is to be justified, it must be because of evils relating to competition, the evils which were vaguely in mind when the Anti-Trust Act of I8go was passed.

The Garfield report mentions "unfair and predatory competition" as an evil-the only evil there specified not already considered. Is this an evil which can be cured by legislation? Are we prepared to define, for purposes of legal restraint, what is unfair in the strife of business, to say distinctly how far competition may go? It will not do to enact simply that competitors shall be fair or that they shall be kind and good to one another, or to turn the Golden Rule into a statute as to traders; even if such enactment is coupled with a scheme which shall tie all who engage in business to the apron strings of a commissioner who shall from day to day pass judgment on their conduct. The purpose of the Anti-Trust Act of 1890 , as found by the courts, is grounded in a desire to keep competition free, to prevent 
what may restrain competition. If it is now suggested that competition be restrained by law, should not the suggestion be accompanied with a clear statement of the proposed restraint? Just why the restraint should be limited to corporations, does not appear. Is there no unfair competition in business not done under corporate organization? But if it is to be so limited, should we be asked to approve the scheme of taking corporations under the charge of the Government in order to prevent unfair competition, without being told what rule of conduct in this respect it is the purpose of the scheme to enforce? The scheme of Federal control is but a means; the end is not revealed.

Mr. Knox in his Pittsburg address, in his list of evils, mentions "discrimination in prices to destroy competition." This is more definite. But are the American people willing to contemplate governmental interference with the right of an individual to buy or not to buy, to sell or not to sell what he owns, and, if he sells, to fix his own prices and terms? If one individual has this right, two in partnership have the same, and so have five persons or more who are associated together in corporate organization. As to railroad rates, the duty of uniformity is based upon the fact that railroad companies exercise powers and perform duties belonging to the state. But the Garfield proposal relates especially to corporations which exercise no such powers and perform no such duties. Their property is not charged with any trust in favor of the public-save such as looks to the protection of creditors-any more than the property of partnerships and individuals. If the state is to regulate the prices at which persons, incorporated or unincorporated, may sell what they own, competition will be killed in the effort to make it fair and business as now conducted must necessarily cease. If we are to go so far toward socialism, why should we stop here? Here again may we not ask for a definite statement of the proposed regulations? Here again the end should be revealed before we are asked to approve the means.

If there is any evil curable by legislation in the great power of large aggregations-which was the idea which led to the Anti-Trust Act of I890-manifestly the legislative remedy should not take in all corporations big and little-this would be to adopt the method of Herod without excuse-but only those whose power is up to such a standard as may be set; and on the other hand it should take in aggregations effected otherwise than through corporate organization. During all the years of agitation on this subject no one has yet been able to suggest any definite limitation upon the combination of capital which could reasonably be enacted. The possibility of any such 
limitation, however, need not be considered in connection with the Garfield proposal, for the speeches and messages of President Roosevelt, the address of Mr. Knox, and the Garfield report all recognize the necessity of aggregations of capital "adequate for the greatest undertakings," and show that it is no part of the present purpose to prohibit the formation or continuance of such aggregations. They are recognized as part of the necessary machinery of modern business competition, especially of ínternational competition.

Where, then, is the justification for this scheme, which is unconstitutional in its purpose, involves "a tremendous change towards centralization," and substitutes an advanced paternalism for libertywhich is, in short, a long step toward Federal socialism?

Thomas Thacher. 